\title{
RANCANG BANGUN TRANDUSER TEMPERATUR MENGGUNAKAN SENSOR TERMISTOR
}

\author{
Wahyu B Mursanto dan Rony Fachrul. \\ Jurusan Teknik Konversi Energi - Politeknik Negeri Bandung \\ email : wahyumursanto@gmail.com; rony.fachrul@yahoo.com
}

\begin{abstract}
Abstrak
Tranduser temperatur ini dibuat dengan menggunakan sensor termistor yang memiliki koefisien negatif atau NTC Termistor memiliki karakteristik non-linier. Dengan karakteristik yang non-linier dilakukan metoda linierisasi menggunakan metoda rangkaian paralel. Tranduser temperatur ini memiliki range pengukuran dari $20^{\circ} \mathrm{C}$ hingga $50^{\circ} \mathrm{C}$. Catu daya DC digunakan sebagai sumber tegangan untuk rangkaian tranduser temperatur. Tranduser ini membutuhkan sebuah rangkaian pengkondisi sinyal agar tegangan keluarannya berkisar pada 2 volt hingga 5 volt. Penggunaan mikrokontroller Atmega 8535 bertujuan untuk mengolah keluaranyang berupa sinyal analog menjadi sebuah sinyal digital yang ditampilkan pada sebuah LCD 16×2.
\end{abstract}

Kata kunci : Tranduser, termistor, mikrokontroller, LCD.

\section{PENDAHULUAN}

Suhu atau temperatur merupakan suatu derajat panas. Pada kehidupan sehari-hari banyak dijumpai di lingkungan sekitar, contohnya temperatur ruangan. Dalam bidang energi, temperatur memiliki peranan yang sangat penting dalam suatu proses kerja sebuah alat. Temperatur tranduser digunakan sebagai alat untuk mendeteksi suhu atau temperatur suatu lingkungan atau suatu sistem. Sebagai seorang yang begerak dalam bidang energi, perlu mengetahui cara untuk memperoleh besaran temperatur dengan menggunakan sebuah instrumen yang terbuat dari suatu rangkaian elektronik.

Pada tranduser temperatur, terdapat elemen-elemen sebagai komponen utama pada suatu rangkaian trandusernya. Elemen sensor yang biasa digunakan pada tranduser temperatur adalah : Termistor, RTD, Elemen IC dan thermokopel. Masing-masing mempunyai karakteristik dan prinsip kerja yang berbedabeda dari keempat elemen tersebut. Termistor memiliki respon yang lebih cepat dibanding yang lain, namun merupakan elemen yang paling tidak linear. Untuk memenuhi kebutuhan respon yang cepat dengan jangkauan yang terbatas, maka termitor merupakan pilihan yang tepat. Untuk mengatasi kekurangan karena ketidaklinieran sensor dapat diatasi dengan menggunakan rangkaian sederhana.

\section{TINJAUAN PUSTAKA}

\section{Tranduser}

Tranduser adalah sebuah piranti yang mampu mengkonversikan suatu besaran fisis tertentu menjdi besaran fisis yang sama atau berbeda [1].

Jenis-jenis sensor temperatur :

1) Termokopel

Berfungsi sebagai sensor suhu rendah dan tinggi, yaitu suhu serendah $-200^{\circ} \mathrm{C}$ sampai dengan suhu tinggi yang digunakan pada proses industri baja, gelas dan keramik yang lebih dari $1400^{\circ} \mathrm{C}$. Termokopel dibentuk dari dua buah penghantar yang berbeda jenisnya dan dililit bersama.

2) Termistor (Thermal Resistor/Thermal Sensitive Resistor)

Termistor berfungsi untuk mengubah suhu menjadi resistansi/hambatan listrik yang sesuai dengan perubahan suhu. Pada termistor jenis NTC (negatif thermistor coefficient) semakin tinggi suhu, semakin kecil resistansi.

3) RTD (Resistance Temperature Detectors)

RTD berfungsi mengubah suhu menjadi resistansi/hambatan listrik yang sebanding dengan perubahan suhu. Semakin tinggi suhu, resistansinya semakin besar. RTD terbuat dari sebuah kumparan kawat platinum yang dilind. RTD dapat digunakan sebagai sensor suhu yang mempunyai ketelitian $0,03^{\circ} \mathrm{C}$ untuk 
temperatur dibawah $500^{\circ} \mathrm{C}$ dan $0,1^{\circ} \mathrm{C}$ di atas $1000^{\circ} \mathrm{C}$.

\section{4) IC Temperatur Tranduser}

Berfungsi untuk mengubah suhu menjadi tegangan/arus tertentu yang sesuai dengan perubahan suhu. Sensor yang berupa IC ini memiliki respon yang lambat dan jangkauan temperatur yang diukur mempunyai jangkauan di bawah $200^{\circ} \mathrm{C}$. IC ini sangat praktis, karena diantara sensor temperature yang ada, sensor IC memiliki keluaran yang paling linier.

\section{Termistor}

Termistor atau tahanan thermal adalah alat semikonduktor yang berkelakuan sebagai tahanan dengan koefisien tahanan temperatur yang tinggi yang biasanya negatif. Umumnya tahanan termistor pada temperatur ruang dapat berkurang $6 \%$ untuk setiap kenaikan temperatur sebesar $1^{\circ} \mathrm{C}$. Kepekaan yang tinggi terhadap perubahan temperatur ini membuat termistor sangat sesuai untuk pengukuran, pengontrolan dan kompensasi temperatur secara presisi. Termistor tebuat dari bahan campuran oksidaoksida logam yang diendapkan seperti; mangan, nikel, kobalt, tembaga, besi dan uranium. Rangkuman tahanannya adalah dari $0,5 \Omega$ sampai 7,5 $\mathrm{M} \Omega$ dan tersedia dalam berbagai bentuk dan ukuran. Ukuran paling kecil adalah berbentuk manik-manik (bads) dengan diameter sebedar $0,15 \mathrm{~mm}$ samnai $1,25 \mathrm{~mm}$. Manikmanik ini dapat disegel dalam ujung batang gelas untuk membentuk jarum penduga (probe) yang sedikit lebih mudah memasangnya dari pada manik-manik. Bentuk piringan (disk) dan cincin wesher dibuat menjadi bentuk silinder datar dengan diameter $2,5 \mathrm{~mm}$ sampai $25 \mathrm{~mm}$ dengan memadatkan bahan termistor dengan temperatur tinggi. Cincin-cincin dapat ditumpukkan secara seri atau paralel guna membesarkan disipasi daya. Gambar 1 memperlihatkan jenis-jenis termistor.

\section{Bentuk termistor}

a. Butiran, digunakan pada suhu $<175^{\circ} \mathrm{C}$ dan memiliki nilai resistansi $16 \Omega$ hingga 1 $\mathrm{M} \Omega$.

b. Keping, digunakan dengan cara direkatkan langsung pada benda yang diukur panasnya.

c. Batang, digunakan untuk memantau perubahan panas pada peralatan elektronik, mempunyai resistansi tinggi dan disipasi dayanya sedang. Termistor dibuat sekecil-kecilnya agar mencapai kecepatan tanggapan (respon time) yang baik.

\section{Termistor tipe NTC(negatif temperature coefficient)}

Termistor jenis ini mempunyai koefisien temperatur negatif atau nilai resistansinya akan berkurang jika temperatur naik. Termistor NTC mempunyai karakteristik yang khas seperti dapat dilihat pada gambar 2. Pada gambar 2 tersebut tampak bahwa hubungan resistansi (keluaran) yang dihasilkan merupakan fungsi yang non-linier terhadap temperatur (masukan).

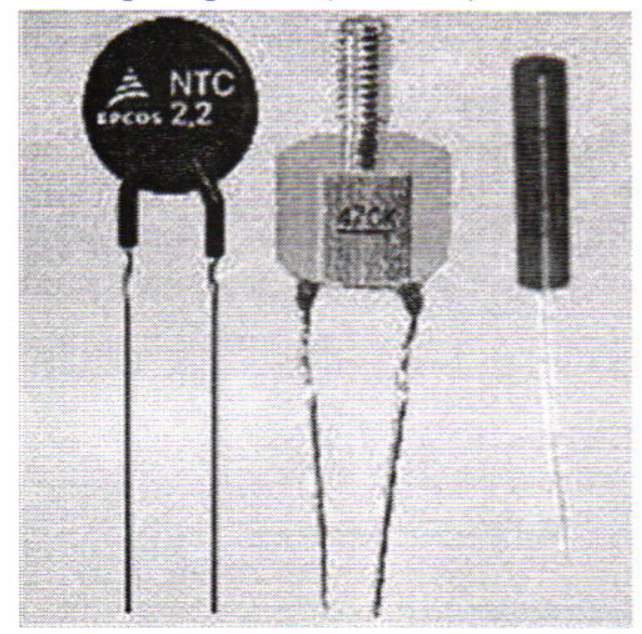

Gambar 1. Jenis-jenis termistor

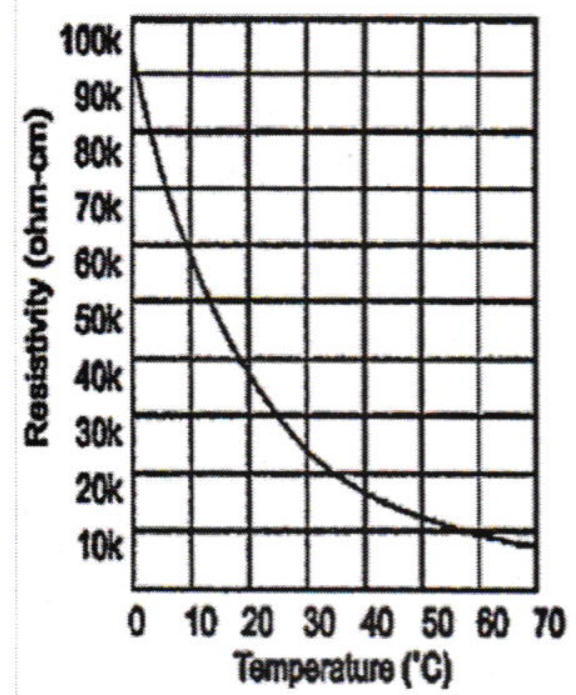

Gambar 2. Karakteristik tahanan vs temperatur 
Tahanan termistor NTC akan berkurang secara eksponensial, jika suhunya bertambah. Hubungan antara tahanan dan suhu termistor diekspresikan pada persamaan (1).

$$
R=R o \cdot L k s p B /
$$

$$
T \text {. }
$$

\section{Dengan:}

$\mathrm{R}=$ tahanan termistor $(\mathrm{Ohm})$ pada suhu $\mathrm{T}$, Ro $=$ Tahanan termistor pada suhu awal To (Ohm),

$\mathrm{B}=$ Konstanta termistor $(\mathrm{K})$ dan $\mathrm{T}=$ Suhu termistor $(\mathrm{K})$.

Konstanta termistor (B) dari persamaan (1) dapat dicari dengan persamaan (2):

$$
B\left(T^{\prime} c\right)=B\left[1+\gamma\left(I^{\prime} c-100\right)\right.
$$

dengan, $\mathrm{B}=$ konstanta termistor $(\mathrm{K})$, tipikalnya sekitar $4000{ }^{\circ} \mathrm{K}$. Tc merupakan temperatur pada saat $\mathrm{T}$ dalam derajat celcius $\left(\mathrm{Tc}=\mathrm{T}-273,15^{\circ} \mathrm{K}\right)$. $\gamma=2,5 \times 10^{-4} / \mathrm{K}$ untuk $\mathrm{T}>100^{\circ} \mathrm{C}$ dan $\gamma=5 \times 10^{-4} / \mathrm{K}$ untuk $\mathrm{T}<100^{\circ} \mathrm{C}$.

Sensitivitas termistor dapat diketahui dengan memakai persamaan (3).

$$
\alpha=\frac{-B}{r^{2}}
$$

dengan, $\alpha=$ sensitifitas termistor, $\mathrm{B}=$ koefisien termistor dalam ${ }^{\circ} \mathrm{K}, \mathrm{T}=$ suhu dalam ${ }^{\circ} \mathrm{K}$. Semakin besar harga $\alpha$ dan $\mathrm{B}$, kualitas termistor semakin baik.

Dengan karakteristik termistor yang tidak linear, maka perlu ditambahkan rangkaian agar menjadi keluaran yang linier. Berikut ini adalah beberapa cara untuk meliniarisasikan. Adapun metoda-metoda yang digunakan ialah :

a. Menggunakan rangkaian paralel.

Rangkaian paralel digunakan untuk melinierkan karakteristik dari termistor. Termistor diparalelkan dengan sebuah resistor R. Gambar 3 memperlihatkan karakteristik linearitas dari termistor yang menggunakan rangkaian paralel.

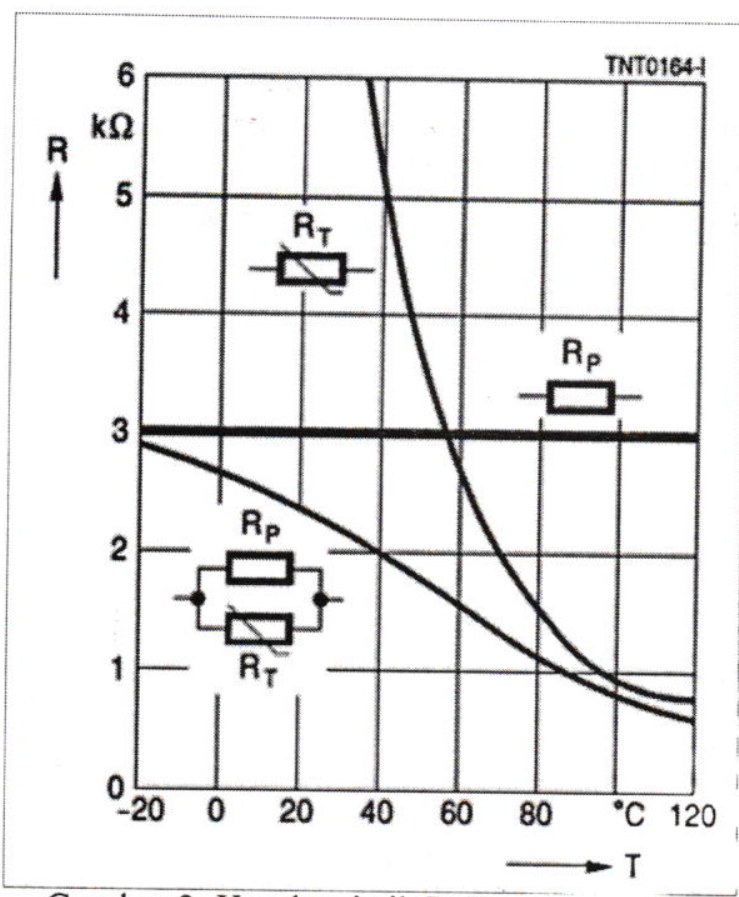

Gambar 3. Karakteristik R-T menggunakan rangkaian parallel

Dari persamaan 4 dapat dicari nilai resistor R yang akan diparalelkan dengan sebuah termistor.

$$
\mathrm{R}_{\mathrm{p}}=\mathrm{R}_{\mathrm{t} . \mathrm{m}} \frac{\beta-2 \mathrm{Tm}}{\beta+2 \mathrm{Tm}}
$$

Dimana $\mathrm{Rp}=$ resistor paralel, $\mathrm{R}_{\mathrm{tm}}=$ tahanan termistor pada temperatur tengah pengukuran, $\beta=$ Konstanta termistor $(\mathrm{K}), \mathrm{T}_{\mathrm{m}}=$ temperatur tengah pengukuran. Persamaan di atas digunakan jika dalam mencari nilai Rp-nya menggunakan $\beta$. Terdapat cara lain untuk menentukan nilai $R_{p}$ dengan menggunakan titik pengukuran minimum $\left(\mathrm{T}_{1}\right)$, titik pengukuran tengah $\left(\mathrm{T}_{2}\right)$, dan titik pengukuran maksimum $\left(\mathrm{T}_{3}\right)$. Dengan menggunakan persamaan 5 dapat diketahui nilai $R_{p}$.

$$
\mathrm{R}_{\mathrm{p}}=\frac{R^{\prime} \cdot 2\left(R^{\prime} T^{\prime} 1+R^{\prime} T^{\prime} 3\right)-2 H^{\prime} 1 R^{\prime} R^{\prime} 3}{R T 1+R T 3-2 R T 2}
$$

Dimana $\mathrm{Rp}=$ resistor paralel, $\mathrm{RT}_{1}=$ tahanan resistor pada temperatur minimum pengukuran, $\mathrm{RT}_{2}=$ tahanan resistor pada temperatur tengah pengukuran, $\mathrm{RT}_{3}=$ tahanan resistor pada temperatur maksimum pengukuran.

\section{Penguat Inverting (Penguat Membalik)}

Inverting amplifier ini, input dan outputnya berlawanan polaritas. Jadi ada 
tanda minus pada rumus penguatannya. Penguatan inverting amplifier adalah bisa lebih kecil nilai besaran dari 1 , misalnya $-0.2,-0.5,-$ 0.7 , dst dan selalu negatif. Besarnya penguatan tergantung pada nilai tahanan umpan baliknya.

Gambar 4 memperlihatkan rangkaian dari sebuah penguat membalik (inverting amolifier).

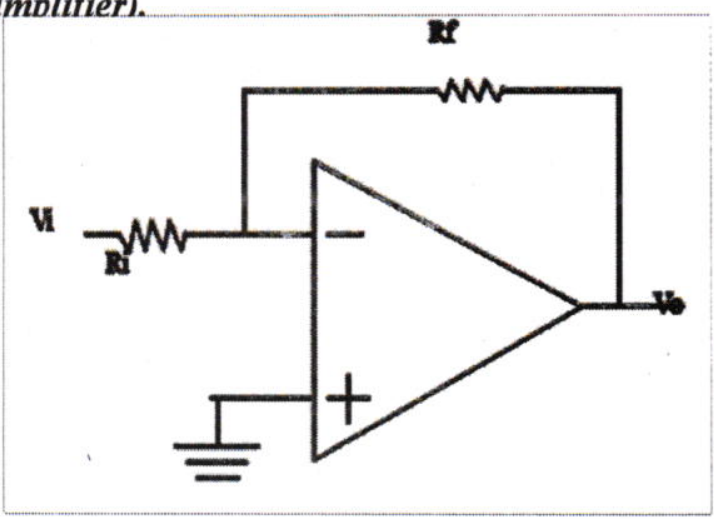

membalik)

Gambar 4 Penguat Inverting (penguat

Besarnya penguatan pada penguat inverting dapat dihitung dengan persamaan 7 .

$$
\mathrm{V}_{\mathrm{o}}=-\frac{R f}{R i} \times V i
$$

Dimana, $\mathrm{V}_{\mathrm{o}}=$ tegangan output (Volt), $\mathrm{Rf}=$ tahanan balik $(\Omega), \mathrm{R}_{\mathrm{i}}=$ tahanan masukan op$\operatorname{amp}(\Omega), V_{\mathrm{i}}=$ tegangan masukan (Volt).

\section{Mikrokontroler [2]}

Mikrokontroler adalah suatu sistem mikroprosesor yang lengkap dan dikemas dalam bentuk sebuah IC (single chip). Mikrokontroler merupakan terobosan teknologi mikroprosesor untuk memenuhi kebutuhan pasar. Sebagai kebutuhan pasar, mikrokontroler hadir untuk memenuhi selera industri dan para konsumen yang menginginkan alat-alat bantu yang lebih baik dan canggih. Atmega 8535 adalah mikrokontroler CMOS 8-bit daya-rendah berbasis arsitektur RISC yang ditingkatkan. Kebanyakan instruksi dikerjakan pada satu siklus clock, Atmega 8535 mempunyai throughput mendekati 1 MIPS per $\mathrm{MHz}$ membuat disainer sistem untuk mengoptimasi konsumsi daya versus kecepatan proses.
Mikrokontroler tipe AVR Atmega 8535 memiliki beberapa kelebihan bila dibandingkan dengan mikrokontroler yang lain, diantaranya :

a) Mempunyai 8 channel ADC yang terintegrasi dengan resolusi 10 bit dengan metode pengkonversian menggunakan Succesive Aproximation.

b) Dilengkapi dengan programmable serial USART.

c) Portal komunikasi serial (USART) dengan kecepatan 2,5 Mbps.

d) Memiliki perangkat antar muka serial TwoWire dengan orientasi byte.

e) Memiliki timer internal yang dapat difungsikan sebagai Real-Time Timer.

f) Memiliki fungsi watchdog timer yang dapat mencegah mikrokontroler dari kesalahan operasi.

g) Memiliki 6 fungsi untuk menghemat energi yang digunakan, yaitu : idle, $A D C$ noise reduction, power save, power down, standby, dan extended standby mode.

h) Memiliki timer yang dapat difungsikan sebagai PWM(Pulse width Modulation).

i) Memiliki 32 buah register untuk user dan 64 buah register yang digunakan sebagai pengontrol fitur-fitur yang terintegrasi dalam mikrokontroler ini.

Atmega 8535 ini memiliki 4 buah port dengan masing-masing berjumlah 8 bit. Konfigurasi pin Atmega 8535 dapat dilihat pada Gambar 5. Secara fungsional konfigurasi pin Atmega8535 sebagai berikut:

a. VCC merupakan pin yang berfungsi sebagai pin masukan catu daya.

b. GND merupakan pin ground.

c. Port A (PA0..PA7) merupakan pin I/O dua arah dan pin masukan ADC.

d. Port B (PB0..PB7) merupakan pin I/O dua arah dan pin fungsi khusus untuk Timer/Counter, Komparator analog, dan SPI.

e. Port $\mathrm{C}(\mathrm{PC} 0 . . \mathrm{PC} 7)$ merupakan pin $\mathrm{I} / \mathrm{O}$ dua arah dan pin khusus untuk TWI, Komparator analog, dan Timer Oscilator.

f. Port D (PD0..PD7) merupakan pin I/O dua arah dan pin khusus untuk Komparator analog, Interupsi eksternal, dan Komunikasi serial. 
g. RESET merupakan pin yang digunakan untuk me-reset mikrokontroller.

h. XTAL1 dan XTAL2 merupakan pin masukan clock eksternal.

i. AVCC merupakan pin masukan tegangan untukADC.

j. AREF merupakan pin masukan tegangan referensiADC.

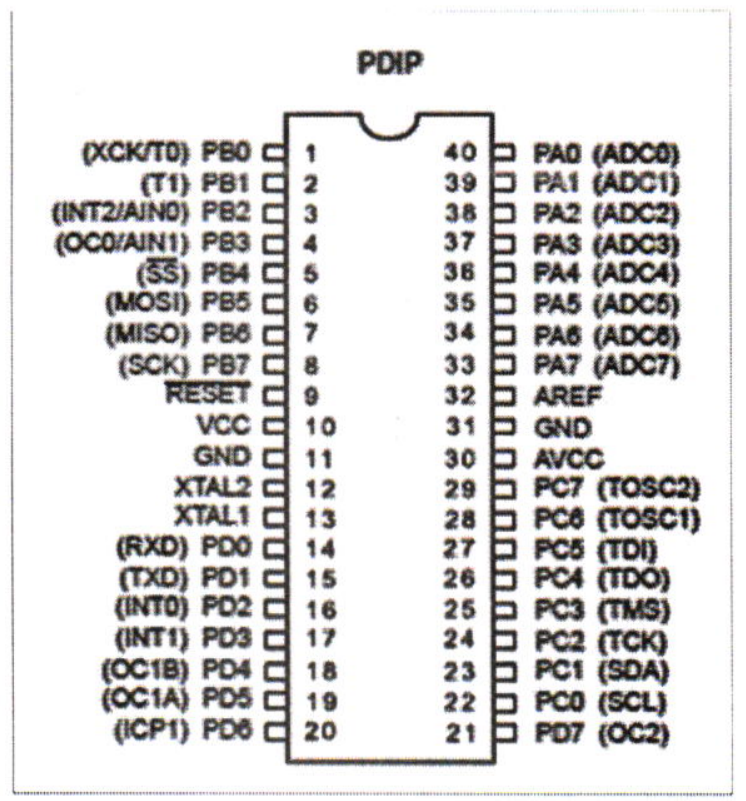

Gambar 5 Konfigurasi pin Atmega 8535 LCD

Liquid Cell Display (LCD) merupakan salah satu alat untuk tampilan. LCD memiliki berbagai macam ukuran mulai dari 1 sampai 4 baris, 16 sampai 40 karakter per baris. Meskipun LCD memiliki berbagai macam ukuran tetapi penggunaannya hampir sama. Pada umumnya LCD memiliki 16 pin yang terbagi atas jalur data, kontrol, power dan backlight. Pada gambar 2.10 merupakan sebuah LCD yang berukuran 16 x 2 dimana LCD ini menampilkan 16 kolom karakter dan 2 baris karakter. Pada gambar 6 merupakan bentuk LCD tipe $16 \times 2$.

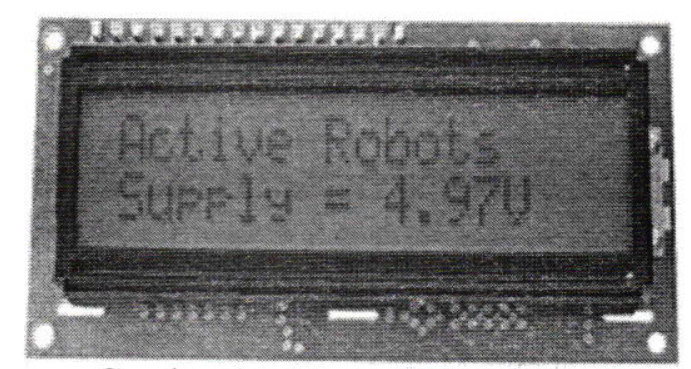

Gambar 6 LCD tipe 16x2

\section{Pembuatan dan Pengujian}

Pada pembuatan tranduser temperatur menggunakan termistor, dibutuhkan beberapa komponen agar menghasilkan output berupa tegangan yang merepresentasikan temperatur yang diukur, oleh krena itu dibutuhkan beberapa komponen elektronik diantaranya ialah : catu daya, dioda, IC LM 7812, IC LM 723, termistor, IC TL 082, resistor, potensio, kapasitor, LED, LCD, dan transformator.

\section{Rangkaian Tranduser Temperatur}

Rangkaian pada gambar 7. merupakan rangkaian dari tranduser temperatur. Termistor dipasang pararel sebelum input pada rangkaian inverting. Tegangan input \pm 12 volt akan melalui termistor yang kemudian menjadikannya tegangan input pada rangkaian inverting. Keluaran dari inverting 1 diumpan balik oleh $\mathrm{R}_{f}$ dan menjadi input pada rangkaian inverting 2 agar keluarannya memiliki polaritas positif [3].

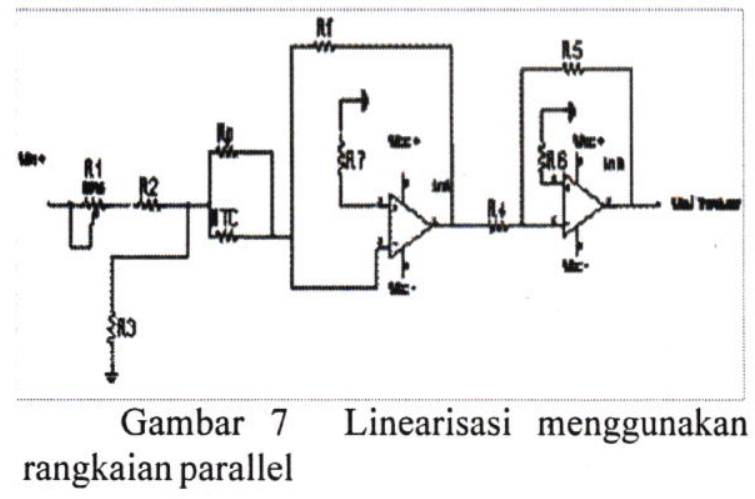

Rangkaian tranduser yang dibuat diberikan tegangan input sebesar 12V. Tahanan R1 dan R2 berfungsi mengatur tegangan yang melewati thermistor. Arus yang melewati termistor kurang dari $100 \mu \mathrm{A}$ agar tidak terjadi pemanasan sendiri(self heating) pada termistor.

\section{Rangkaian Pengkondisi Sinyal}

Rangkaian pengkondisi sinyal merupakan sebuah rangkaian untuk mengkondisikan sinyal keluaran dari sebuah tranduser. Rangkaian pengkondisi sinyal ini biasa disebut sebagai rangkaian span and zero. Rangkaian span and zero ini merupakan sebuah rangkaian penguat operasional. Pada alat yang dibuat digunakan rangkaian span and zero yang merupakan rangkaian penguat penjumlah. Gambar 8 memperlihatkan rangkaian span and zero [4]. 


\section{Tranduser Temperatur yang Dibuat}

Gambar-9 memperlihatkan foto tranduser temperatur yang dibuat. Semua blok rangkaian, mulai dari rangkaian catu daya, rangkaian tranduser, rangkaian pengkondisi sinyal, rangkaian mikrokontroler, dan LCD dijadikan satu dalam sebuah box.

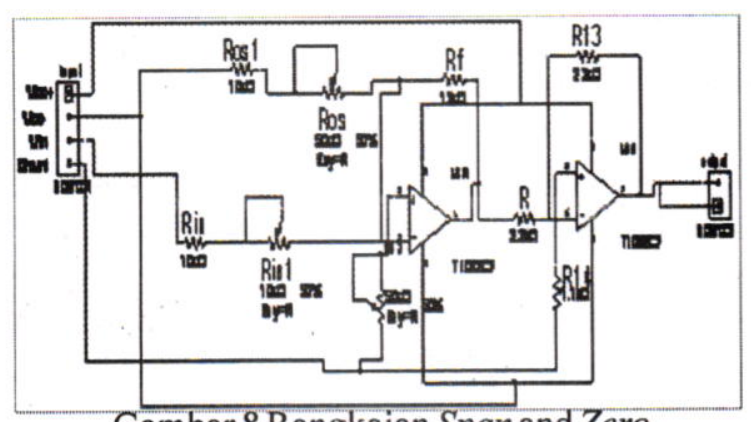

Gambar 8 Rangkaian Span and Zero

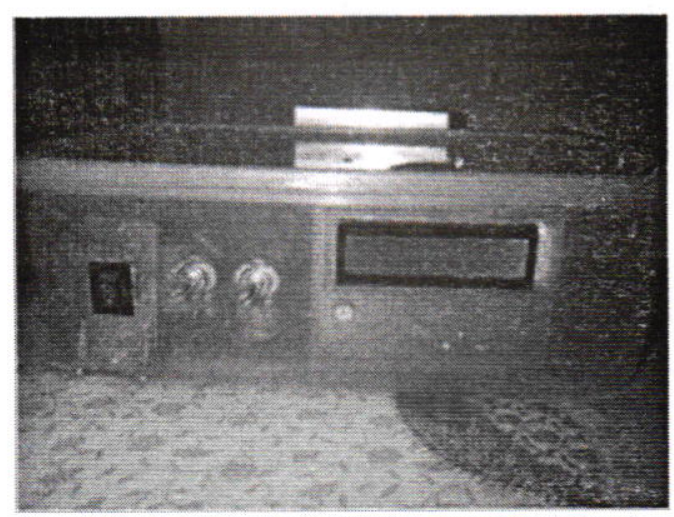

Gambar 9 Tranduser Temperatur

\section{Pengujian Alat}

Pengujian dilakukan dengan menguji tahanan termistor dan rangkaian tranduser. Dengan menguji tahanan termistor dapat diketahui karakteristik termistor dan karakteristik linearisasinya. Pengujian alat diakukan dengan memasangkan semua rangkaian dari catu daya hingga ke rangkaian pengkondisi sinyal. Pengujian dilakukan dengan cara memasukkan termistor ke dalam gelas kimia yang berisi air. Air dikondisikan sesuai temperatur yang menjadi batas pengukuran. Gambar 10 memperlihatkan foto pengujian. Parameter yang ada dicatat sebagai data untuk dianalisis. Pengujian ini menggunakan thermometer digital yang digunakan sebagai standar pengukuran. Pengkondisian media yang berupa air dilakukan melalui pemanasan dan pengadukan agar temperatur terdistribusi secara merata di semua tempat.

\section{Data dan Pengamatan}

Hasil pengujian kemudian dicatat dan ditabelkan sebagaimana ditunjukkan pada tabel-1. Tabel-1 memperlihatkan data karakteristik statik termistor yang digunakan.

Tabel 1. Tabel Pengamatan Tranduser Temperatur

\begin{tabular}{|c|c|c|c|}
\hline Temp. & Thermometer & NTC & $\mathrm{Rp}$ \\
\hline${ }^{\circ} \mathrm{C}$ & ${ }^{\circ} \mathrm{C}$ & $\mathrm{ohm}$ & ohm \\
\hline 20 & 20 & 2500 & 1084 \\
\hline 21 & 21 & 2410 & 1084 \\
\hline 22 & 22,1 & 2310 & 1084 \\
\hline 23 & 23 & 2266 & 1084 \\
\hline 24 & 24,1 & 2208 & 1084 \\
\hline 25 & 25 & 2125 & 1084 \\
\hline 26 & 26,1 & 2044 & 1084 \\
\hline 27 & 27 & 1985 & 1084 \\
\hline 28 & 28,1 & 1905 & 1084 \\
\hline 29 & 28,9 & 1836 & 1084 \\
\hline 30 & 30 & 1775 & 1084 \\
\hline 31 & 31 & 1732 & 1084 \\
\hline 32 & 32,1 & 1660 & 1084 \\
\hline 33 & 33 & 1590 & 1084 \\
\hline 34 & 34,1 & 1540 & 1084 \\
\hline 35 & 35 & 1480 & 1084 \\
\hline 36 & 36 & 1434 & 1084 \\
\hline 37 & 37 & 1393 & 1084 \\
\hline 38 & 38 & 1355 & 1084 \\
\hline 39 & 38,9 & 1303 & 1084 \\
\hline 40 & 40 & 1250 & 1084 \\
\hline 41 & 41,1 & 1204 & 1084 \\
\hline 42 & 42 & 1166 & 1084 \\
\hline 43 & 43 & 1142 & 1084 \\
\hline 44 & 44 & 1126 & 1084 \\
\hline 45 & 45,1 & 1108 & 1084 \\
\hline 46 & 46 & 1085 & 1084 \\
\hline 47 & 46,9 & 1043 & 1084 \\
\hline 48 & 48 & 1000 & 1084 \\
\hline 49 & 49,1 & 968 & 1084 \\
\hline 50 & 50,1 & 938 & 1084 \\
\hline
\end{tabular}

Tabel-2 memperlihatkan data keluaran di rangkaian transduser dan di rangkaian zero dan span. 


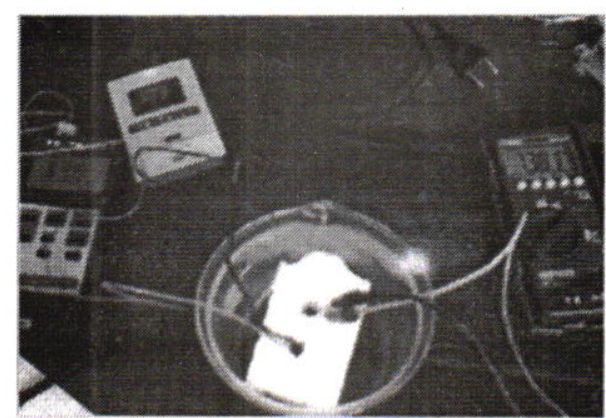

Gambar 10. Pengujian tranduser temperatur

Tabel-2 Data output

\begin{tabular}{|c|c|c|}
\hline $\begin{array}{c}\text { R } \\
\text { linearitas }\end{array}$ & $\begin{array}{c}\mathrm{V} \\
\text { tranduser }\end{array}$ & $\begin{array}{c}\mathrm{V} \\
\text { span } \\
\text { zero }\end{array}$ \\
\hline ohm & volt & volt \\
\hline 756,14 & 1995,785 & 1,990 \\
\hline 747,69 & 2018,328 & 2,051 \\
\hline 737,78 & 2045,435 & 2,135 \\
\hline 733,24 & 2058,120 & 2,174 \\
\hline 727,06 & 2075,614 & 2,228 \\
\hline 717,82 & 2102,309 & 2,311 \\
\hline 708,34 & 2130,452 & 2,398 \\
\hline 701,12 & 2152,396 & 2,466 \\
\hline 690,87 & 2184,323 & 2,565 \\
\hline 681,58 & 2214,094 & 2,657 \\
\hline 673,00 & 2242,341 & 2,745 \\
\hline 666,72 & 2263,449 & 2,810 \\
\hline 655,77 & 2301,240 & 2,928 \\
\hline 644,56 & 2341,263 & 3,052 \\
\hline 636,19 & 2372,078 & 3,147 \\
\hline 625,71 & 2411,805 & 3,270 \\
\hline 617,34 & 2444,513 & 3,372 \\
\hline 609,61 & 2475,488 & 3,468 \\
\hline 602,22 & 2505,869 & 3,562 \\
\hline 591,73 & 2550,315 & 3,700 \\
\hline 580,55 & 2599,421 & 3,852 \\
\hline 570,43 & 2645,546 & 3,995 \\
\hline 561,75 & 2686,395 & 4,122 \\
\hline 556,12 & 2713,594 & 4,206 \\
\hline 552,30 & 2732,371 & 4,264 \\
\hline 547,93 & 2754,144 & 4,332 \\
\hline 542,25 & 2783,016 & 4,421 \\
\hline 531,55 & 2839,024 & 4,595 \\
\hline 520,15 & 2901,239 & 4,788 \\
\hline 511,36 & 2951,127 & 4,910 \\
\hline 502,86 & 2995,638 & 5,000 \\
\hline & & \\
\hline 75
\end{tabular}

Dari tabel data yang diperoleh kemudian dibuat grafik yang menunjukkan karakteristik dari NTC dan tranduser temperatur yang dibuat. Pada gambar 11 terlihat hubungan antara karakteristik NTC dan metoda linierisasi menggunakan rangkaian paralel. Karakteristik NTC yang tidak linear terlihat pada gambar, terlihat bahwa dengan menambahkan sebuah tahanan yang disusun secara shunt/parallel membuat karakteristik dari nilai resistansinya menjadi lebih linier

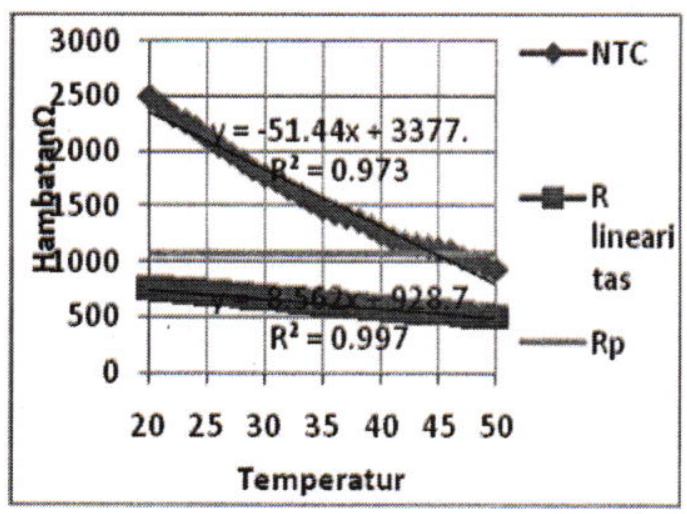

Gambar 11. Karakteristik NTC \& linearisasi NTC

Terlihat pada garis yang menunjukkan karakteristiknya, nilai gradien dari kedua garis memiliki nilai yang berbeda. Pada garis NTC memiliki gradien yang lebih besar dari pada gradien pada garis NTC yang telah dilinearkan. Pada grafik di atas terlihat garis merah lebih linier dibandingkan dengan garis biru. Hal ini menunjukkan NTC telah linier. Kelinieran dari NTC terlihat pada grafik temperatur terhadap tegangan.

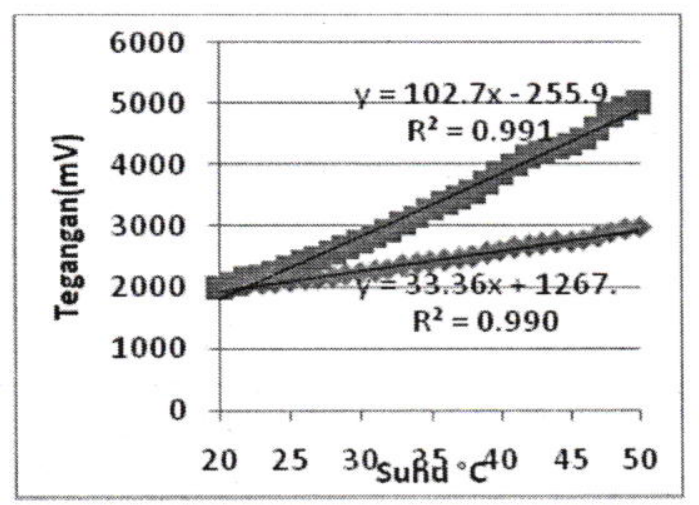

Gambar 12. Karakteristik Suhu terhadap Vout. 
Gambar 12 memperlihatkan grafik hubungan antara temperatur dan tegangan. Garis biru ravane lanclteristik dari trandusar yang … : t..... guis merah merupakan karc:ter:stik ceri rarilkaian pengkondisi sinyal.

Dari grafik terlihat karakteristik tranduser hanya memiliki tegangan maksimal pada keluarannya sebesar 3 Volt. Dengan menggunakan pengkondisi sinyal dapat dibuat keluarannya dari 2 Volt hingga 5 Volt. Pada grafik, garis biru yang menggambarkan karakteristik dari sebuah tranduser dari termistor NTC memiliki garis yang linier pada keluarannya (tegangan output tranduser). Pada takei cii atas, tahanan termistor setelah

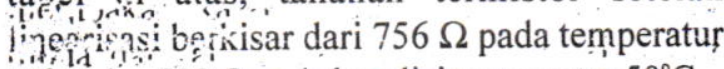
$50^{\circ} \mathrm{C}$ dan $502 \Omega$ pada kondisi temperatur $50^{\circ} \mathrm{C}$.

\section{Simpulan}

Beberapa simpulan yang dapat diambil dảri hasil pengujian tranduser temperatur yang telah dibuat adalah :

1. Tahanan termistor memiliki range $2500 \Omega$ pada témperatur $20^{\circ} \mathrm{C}$ dan $938 \Omega$ pada temperatur $50^{\circ} \mathrm{C}$.

2. Tegangan output pada tranduser berkisar dari 2 Volt pada kondisi temperatur $20^{\circ} \mathrm{C}$ hingga 3 Volt pada temperatur $50^{\circ} \mathrm{C}$.

3: Tegangar "dari pengkondisi sinyal telah tercapai dengan masukan tegangan yang hanya $2 \mathrm{~V}$ hingga $3 \mathrm{~V}$ dari tranduser menjadi $2 \mathrm{~V}$ hingga $5 \mathrm{~V}$.

4. Dengan metoda linierisasi, tahanan pada termistor menjadi lebih linier.

5. Termistor linierisasi memiliki kenaikan sekitar $\pm 60 \Omega$ setiap $/{ }^{\circ} \mathrm{C}$ dan $\pm 40 \mathrm{mV} /{ }^{\circ} \mathrm{C}$.

Notasi

$\begin{array}{lll}\mathrm{R} & \text { Hambatan } & {[\text { ohm] }} \\ \mathrm{V} & \text { Tegangan } & {[\text { Volt] }} \\ \mathrm{T} & \text { Temperatur } & {[\text { Kelvin] }} \\ \mathrm{I} & \text { Arus } & {[\text { Amper] }}\end{array}$

\section{DAFTAR PUSTAKA}

1. Areny, Ramon Pallas. dan John G. Webster. 1991.Sensors And Signal Conditioning. Amerika Serikat: John Wiley \& Sons, Inc.

2. Budiharto, Widodo dan Sigit Firmansyah. 2005. Elektronika Digital Dan Mikroprosesor. Yogyakarta:ANDI
3. Coughlin, Robert F. Dan Frederick F. Driscoll. 1994. Penguat Operasional Dan Rangkaian Terpadu Lincar. Jakurta: Erlangga.

4. Tompkins, Willis J. dan John G. Webster.(Editor). 1983. Interfacing Sensor To The IBM PC. University Of WisconsinMadison. 